\title{
Menopause leads to elevated expression of macrophage-associated genes in the aging frontal cortex: rat and human studies identify strikingly similar changes
}

Miklós Sárvári ${ }^{1 *}$, Erik Hrabovszky ${ }^{1}$, Imre Kalló ${ }^{1,2}$, Norbert Solymosi ${ }^{3}$, István Likó ${ }^{4}$, Nicole Berchtold ${ }^{5}$, Carl Cotman ${ }^{5}$ and Zsolt Liposits ${ }^{1,2}$

\begin{abstract}
Background: The intricate interactions between the immune, endocrine and central nervous systems shape the innate immune response of the brain. We have previously shown that estradiol suppresses expression of immune genes in the frontal cortex of middle-aged ovariectomized rats, but not in young ones reflecting elevated expression of these genes in middle-aged, ovarian hormone deficient animals. Here, we explored the impact of menopause on the microglia phenotype capitalizing on the differential expression of macrophage-associated genes in quiescent and activated microglia.

Methods: We selected twenty-three genes encoding phagocytic and recognition receptors expressed primarily in microglia, and eleven proinflammatory genes and followed their expression in the rat frontal cortex by real-time PCR. We used young, middle-aged and middle-aged ovariectomized rats to reveal age- and ovariectomy-related alterations. We analyzed the expression of the same set of genes in the postcentral and superior frontal gyrus of pre- and postmenopausal women using raw microarray data from our previous study.
\end{abstract}

Results: Ovariectomy caused up-regulation of four classic microglia reactivity marker genes including Cd11b, Cd18, $\mathrm{Cd} 45$ and $\mathrm{Cd} 86$. The change was reversible since estradiol attenuated transcriptional activation of the four marker genes. Expression of genes encoding phagocytic and toll-like receptors such as Cd11b, Cd18, C3, Cd32, Msr2 and TIr4 increased, whereas scavenger receptor Cd36 decreased following ovariectomy. Ovarian hormone deprivation altered the expression of major components of estrogen and neuronal inhibitory signaling which are involved in the control of microglia reactivity. Strikingly similar changes took place in the postcentral and superior frontal gyrus of postmenopausal women.

Conclusions: Based on the overlapping results of rat and human studies we propose that the microglia phenotype shifts from the resting toward the reactive state which can be characterized by up-regulation of CD11b, CD14, CD18, CD45, CD74, CD86, TLR4, down-regulation of CD36 and unchanged CD40 expression. As a result of this shift, microglial cells have lower threshold for subsequent activation in the forebrain of postmenopausal women.

Keywords: Frontal cortex, Rat, Ovarian hormones, Expression analysis, Microglia activation, Postmenopausal women

\footnotetext{
* Correspondence: sarvari@koki.hu

${ }^{1}$ Laboratory of Endocrine Neurobiology, Institute of Experimental Medicine, Hungarian Academy of Sciences, Szigony utca 43, Budapest 1083, Hungary Full list of author information is available at the end of the article
} 


\section{Background}

The intricate interactions between the immune, endocrine and central nervous systems shape the immune response within the brain [1-3]. The ovarian hormone $17 \beta$-estradiol (E2) exerts potent immunomodulatory effects in neuroinflammatory models [3-7]. Both neurons [8] and glial cells [9] express the two classical estrogen receptors (ER), ER $\alpha$ and $E R \beta$, which mediate the neuroprotective [10,11] and anti-inflammatory [6,12] activities of E2. Progesterone and its metabolite allopregnanolone exert estrogen-modifying and immunomodulatory effects in injury [13,14] and inflammatory [15] models. We have previously shown that E2 suppresses the expression of genes associated with the innate immune system in the frontal cortex of middle-aged ovariectomized (OVX) rats [16]. E2-regulated immune genes encode MHC class I and class II (RT1-Aw2, Cd74), Fcy receptors (Fcgr2a, Fcgr2b), and complement proteins (C3, C4b). In contrast, E2 has no effect on the expression of the same set of genes in the same region of young OVX rats [17] reflecting elevated expression of these immune genes in the frontal cortex of middleaged, ovarian hormone-deficient rats. This notion is supported by the results of human [18-20] and rodent $[21,22]$ microarray studies demonstrating up-regulation of immune genes in the cerebral cortex during the course of normal aging. Up-regulation of MHC class I and class II, toll-like receptor, complement and cytokine genes has been shown to be a characteristic feature of aging in both sexes, with proportionally higher expression in women indicating sexually dimorphic changes [20].

In this study, we explored the impact of menopause on the expression of genes related to the innate immune system in the rat and human cerebral cortex. We focused on the potential alteration of the microglia phenotype as microglial cells play pivotal roles in the initiation and regulation of the immune response. It is important to note that in the adult brain, there is no exchange of microglial cells under physiological conditions [23-25]. We took advantage of the differential expression of macrophage-associated genes in resting and activated microglia [25-28]. Although the microglial response is signal-specific, activated microglia unfold strong macrophage characteristics and express elevated levels of phagocytic [29], scavenger [30] and toll-like [31] receptors (Tlrs), MHC antigens [32]. Previous studies have established that in the case of macrophage-associated genes, mRNA expression correlates well with protein expression [27,33]. Therefore, we selected thirty-four genes including twenty-three macrophage-associated and eleven complement and cytokine genes, and analyzed their mRNA expression by real-time PCR. We found up-regulation of several macrophage-associated and some complement genes in the frontal cortex of middle-aged OVX rats. To demonstrate the relevance of these observations to human menopause, we analyzed the expression of the same set of genes using raw microarray data from the postcentral gyrus and superior frontal gyrus of pre- and postmenopausal women [20]. Data analysis revealed changes highly similar to the ones we observed in the rat menopausal model. Based on these results we characterized the microglia phenotype in the forebrain of postmenopausal women.

\section{Methods \\ Reagents}

E2 was purchased from Sigma (St. Louis, MO, USA). Alzet osmotic minipumps (model 2004) were obtained from Durect (Cupertino, CA, USA). Microfluidic cards, PCR and reverse transcription reagents were ordered from Applied Biosystems (Foster City, CA, USA).

\section{Experimental animals and treatments}

Female Harlan-Wistar rats were purchased from Toxicoop (Budapest, Hungary). Animals were housed individually on a 12-h light/12-h dark cycle, with unrestricted access to phytoestrogen-free rodent diet (Harlan Teklad Global Diets, Madison, WI, USA). We applied four rat models: young adult, 2 month-old rats with low E2 levels (Y group), middle-aged, 13-month old intact female rats ( $\mathrm{M}$ group), middle-aged OVX rats (M/OVX group), and middle-aged OVX rats with chronic E2 treatment (M/OVX+E2 group). For the young adult group we chose young OVX rats, since ovariectomy did not result in changes of macrophageassociated genes, as we reported earlier addressing the effect of E2 treatment in this model [17]. Bilateral ovariectomy of young $(\mathrm{n}=10)$ and middle-aged $(\mathrm{n}=20)$ rats was performed under deep anesthesia. Animals in the $M$ group $(\mathrm{n}=9)$ were sham-operated. After surgery, rats were housed individually and ten days later, received treatments with vehicle. E2 replacement in middle-aged OVX rats was carried out as described earlier [16].

On the day of sample preparation, animals were deeply anesthetized and perfused transcardially with $100 \mathrm{ml}$ of cold fixative solution containing $10 \%$ RNAlater in phosphate-buffered saline. In all experiments, the same procedure was followed for the preparation of the frontal cortex as published earlier [17]. Protocols were reviewed and approved by the Animal Welfare Committee of the Institute of Experimental Medicine (Number A5769-01, permission from the Department of Epidemiology and Animal Welfare, Municipal Agriculture Office, Budapest, Hungary). Experiments were carried out in accordance with the legal requirements of the European Community (Decree 86/609/EEC). 


\section{Total RNA isolation from the frontal cortex}

Total RNA was isolated from cortical samples using the RNeasy Lipid Tissue Mini Kit (Qiagen, Hilden, Germany). RNA analytics included A260nm/A280nm readings using a Nanodrop Spectrophotometer and capillary electrophoresis using RNA Nano Chips with the 2100 Bioanalyzer (Agilent, Santa Clara, CA, USA). All RNA samples displayed RNA integrity numbers above 8.2.

\section{Quantitative real-time PCR}

Custom TaqMan low density arrays (TLDA) were designed to study in depth the regulation of thirty-four macrophage-associated and immune genes by quantitative real-time PCR. Microfluidic cards (Applied Biosystems, Santa Clara, CA, USA) were preloaded by the manufacturer with selected inventoried assays for the genes of our interest (Table 1) and for five potential house-keeping genes including $18 \mathrm{~S}$ rRNA, glyceraldehyde-3-phosphate dehydrogenase (Gapdh), glucuronidase beta (Gusb), hypoxanthine guanine phosphoribosyl-transferase (Hprt) and peptidyl-prolyl isomerase A (Ppia). Each assay consisted of a FAM dye-labeled TaqMan MGB probe and two PCR primers. Reverse transcription and real-time PCR were run as described earlier [16]. The RealTime StatMiner (Integromics, Granada, Spain) software and relative quantification against calibrator samples $(\Delta \Delta \mathrm{Ct})$ were used for analysis. To find the most stable endogenous controls, the normfinder stability scoring method [34] was used. A computed internal control corresponding to the geometric mean of cycle threshold $(\mathrm{Ct})$ values of selected housekeeping genes was used for $\Delta \mathrm{Ct}$ calculation [35].

\section{Analysis of human microarray data}

Files [GEO: GSE11882] [20], contained microarray data from four regions of the forebrain: postcentral gyrus (PG), superior frontal gyrus (SG), entorhinal cortex, hippocampus. As menopause occurs between 50 and 53 years of age [36,37], this analysis included female cases divided into two age groups. The first group consisted of the putatively premenopausal subjects between 25 and 50 years of age, the second included postmenopausal women between 60 and 78 years of age. Importantly, we excluded subjects above 80 years of age since at this time significant age-related alterations occur in the cortical transcriptome. From the data set, we analyzed PG and SG, which were relevant to compare with the rat frontal cortex. Sample size (n), average age (age) in years and standard deviation of age (SD) were used to characterize the premenopausal PG $\left(\mathrm{n}_{\mathrm{PG}}=7, \operatorname{age}_{\mathrm{PG}}=38.9, \mathrm{SD}_{\mathrm{PG}}=7.9\right)$ and $\mathrm{SG}\left(\mathrm{n}_{\mathrm{SG}}=10\right.$, age $\left.\mathrm{SG}_{\mathrm{SG}}=39.1, \mathrm{SD}_{\mathrm{SG}}=7.6\right)$, and postmenopausal PG $\left(\mathrm{n}_{\mathrm{PG}}=5\right.$, age $\left.\mathrm{PG}_{\mathrm{PG}}=71.2, \mathrm{SD}_{\mathrm{PG}}=4.4\right)$ and $\mathrm{SG}$ $\left(\mathrm{n}_{\mathrm{SG}}=6\right.$, age $\left._{\mathrm{SG}}=71.7, \mathrm{SD}_{\mathrm{SG}}=4.1\right)$ data. Raw microarray data were pre-processed for analysis by GC robust multi-array average (GCRMA) [38]. From the expression set, probesets were selected based on the relevance to rat data. After annotation, we identified twenty-nine human genes with high confidence (Table 2). Difference analysis of gene expression was performed by linear models combined with empirical Bayesian methods [39]; $P$ was adjusted by the false discovery rate-based method [40]. In all statistical and data mining work, Bioconductor packages [41] in R-environment were used.

\section{Results}

Age and ovarian hormone deficiency led to elevation in mRNA expression of $\mathrm{Cd} 11 \mathrm{~b}, \mathrm{Cd} 18, \mathrm{Cd} 45, \mathrm{Cd} 74$ and $\mathrm{Cd} 86$ in the frontal cortex of middle-aged female rats

We explored the impact of ovarian hormone deficiency on mRNA expression of six genes encoding the alpha and beta chain of complement receptor (CR) type 3 (Cd11b and Cd18), TNF receptor superfamily member 5 (Cd40), leukocyte common antigen (Cd45), MHC class II-associated invariant chain (Cd74) and B72 antigen (Cd86). These receptors are widely considered as markers of microglia reactivity $[25,27]$. As a result of ovariectomy, we found a 1.5- to 2.0-fold increase in mRNA expression of Cd11b (Figure 1A), Cd18 (Figure 1B), Cd45 (Figure 1D) and Cd86 (Figure 1F). Other markers such as Cd40 (Figure 1C) and Cd74 (Figure 1E) did not change.

We determined age-related changes in the expression of these marker genes by comparing middle-aged rats to young ones. As a result of aging, we found a 1.4-fold enhancement in Cd11b (Figure 1A), 2.0-fold increase in Cd74 (Figure 1E) and 1.2-fold elevation in the other four genes. In the case of $\mathrm{Cd} 11 \mathrm{~b}, \mathrm{Cd} 18, \mathrm{Cd} 45$ and $\mathrm{Cd} 86$, ovarian hormone deficiency-related alterations exceeded age-related ones underscoring the importance of ovarian hormones on microglial gene expression. Altogether, age and ovarian hormone deficiency resulted in an average of 2.0-fold elevation in the expression of the marker genes, with the exception of Cd40 (Table 1). It is noteworthy that Nos2 was not induced (Table 1).

We studied the effect of E2 replacement on the ovariectomy-dependent increase of marker genes. E2 attenuated the enhancement of Cd11b, Cd18, Cd45 and Cd86 (Figure 1). These results indicated that alterations in the expression of microglia marker genes were reversible, at least in part, following ovariectomy.

\section{Ovariectomy-dependent changes in the expression of genes related to phagocytosis}

In addition to Cd11b and Cd18, we examined age- and ovariectomy-related alterations in the expression of $\mathrm{Fcy}$ receptor 2a (Cd32), phagocytic $\mathrm{Clq}$ receptor (Cd93), macrophage scavenger receptor 2 (Msr2) and leukocyte 
Table 1 Age- and ovarian hormone-related changes in expression of genes related to microglial reactivity in the frontal cortex of middle-aged female rats

\begin{tabular}{|c|c|c|c|c|c|c|c|}
\hline Symbol & Taqman assay ID & RQ (age) & $P$ (age) & RQ (OVX) & $P(\mathrm{OVX})$ & RQ (age+OVX) & $P$ (age+OVX) \\
\hline \multicolumn{8}{|c|}{ Macrophage-associated genes } \\
\hline \multicolumn{8}{|c|}{ Phagocytic and scavenger receptors } \\
\hline$C d 11 b^{b}$ & Rn00709342_m1 & $1.389^{\mathrm{a}}$ & 0.044 & $2.000^{\mathrm{a}}$ & $<0.001$ & $2.778^{\mathrm{a}}$ & $<0.001$ \\
\hline $\mathrm{Cd} 18^{\mathrm{b}}$ & Rn01427948_m1 & 1.206 & & $1.488^{\mathrm{a}}$ & 0.001 & $2.164^{\mathrm{a}}$ & $<0.001$ \\
\hline Cd93 & Rn00584525_g1 & 1.271 & 0.082 & 0.796 & 0.051 & 1.012 & \\
\hline Fcgrab & Rn00598391_m1 & $1.560^{\mathrm{a}}$ & 0.024 & $1.595^{\mathrm{a}}$ & $<0.001$ & $2.488^{\mathrm{a}}$ & $<0.001$ \\
\hline Msr2 & Rn01455191_m1 & 2.630 & & $1.353^{\mathrm{a}}$ & 0.025 & $3.558^{\mathrm{a}}$ & 0.003 \\
\hline Cd36 & Rn00580728_m1 & $0.567^{\mathrm{a}}$ & $<0.001$ & $0.776^{\mathrm{a}}$ & 0.012 & $0.440^{\mathrm{a}}$ & $<0.001$ \\
\hline Rage & Rn00584249_m1 & 1.225 & & 0.870 & & 1.066 & \\
\hline \multicolumn{8}{|c|}{ Recognition receptors } \\
\hline $\mathrm{Cd} 14$ & Rn00572656_g1 & 0.844 & & 1.391 & & 1.174 & \\
\hline $\mathrm{Cd} 40^{\mathrm{b}}$ & Rn01423590_m1 & 1.496 & 0.087 & 0.990 & & 1.481 & 0.054 \\
\hline $\mathrm{Cd} 45^{\mathrm{b}}$ & Rn00709901_m1 & 1.196 & & $1.504^{\mathrm{a}}$ & $<0.001$ & $1.799^{\mathrm{a}}$ & $<0.001$ \\
\hline $\mathrm{Cd} 86^{\mathrm{b}}$ & Rn00571654_m1 & 1.178 & & $1.513^{\mathrm{a}}$ & 0.001 & $1.782^{\mathrm{a}}$ & $<0.001$ \\
\hline Tlr2 & Rn02133647_s1 & 1.015 & & 1.000 & & 1.015 & \\
\hline Tlr4 & Rn00569848_m1 & 1.207 & & $1.253^{\mathrm{a}}$ & 0.006 & $1.512^{\mathrm{a}}$ & $<0.001$ \\
\hline Tlr9 & Rn01640054_m1 & $1.452^{\mathrm{a}}$ & 0.033 & 1.348 & & $1.907^{\mathrm{a}}$ & 0.008 \\
\hline RT1-Aw2 & Rn03034964_u1 & $14.696^{\mathrm{a}}$ & $<0.001$ & $1.479^{\mathrm{a}}$ & 0.001 & $21.735^{a}$ & $<0.001$ \\
\hline RT1-N1 & Rn00561858_m1 & $0.588^{a}$ & 0.046 & $3.300^{\mathrm{a}}$ & $<0.001$ & $1.941^{\mathrm{a}}$ & $<0.001$ \\
\hline $\mathrm{Cd} 74$ & Rn00565062_m1 & $2.379^{\mathrm{a}}$ & 0.031 & 0.948 & & $2.255^{\mathrm{a}}$ & 0.047 \\
\hline \multicolumn{8}{|l|}{ Signaling } \\
\hline Nos2 & Rn00561646_m1 & 0.971 & & 1.072 & & 1.041 & \\
\hline Irf7 & Rn01450778_g1 & 1.855 & & $2.519^{\mathrm{a}}$ & $<0.001$ & $4.748^{\mathrm{a}}$ & $<0.001$ \\
\hline Irf9 & Rn01489163_m1 & $1.332^{\mathrm{a}}$ & 0.030 & $1.311^{\mathrm{a}}$ & 0.004 & $1.746^{\mathrm{a}}$ & $<0.001$ \\
\hline
\end{tabular}

Regulatory genes for microglia reactivity

Microglial receptors

\begin{tabular}{|c|c|c|c|c|c|c|c|}
\hline $\mathrm{Cd} 47$ & Rn00569914_m1 & 0.884 & 0.084 & $1.189^{\mathrm{a}}$ & 0.041 & 1.051 & \\
\hline $\mathrm{Cd} 200 \mathrm{r}$ & Rn00576646_m1 & $0.821^{\mathrm{a}}$ & 0.005 & 0.880 & 0.069 & $0.722^{\mathrm{a}}$ & $<0.001$ \\
\hline $\mathrm{C} \times 3 \mathrm{cr} 1$ & Rn00591798_m1 & $1.375^{\mathrm{a}}$ & 0.006 & 0.975 & & $1.341^{\mathrm{a}}$ & 0.005 \\
\hline \multicolumn{8}{|c|}{ Neuronal ligands } \\
\hline $\mathrm{Cd} 200$ & Rn00580478_m1 & 0.945 & & 0.878 & 0.088 & $0.829^{\mathrm{a}}$ & 0.019 \\
\hline Sirpa & Rn00564609_m1 & 0.922 & & 1.071 & & 0.987 & \\
\hline $\mathrm{Cx} 3 \mathrm{cl} 1$ & Rn00593186_m1 & 0.928 & & $0.813^{\mathrm{a}}$ & $<0.001$ & $0.754^{\mathrm{a}}$ & $<0.001$ \\
\hline \multicolumn{8}{|c|}{ Complement and cytokine genes } \\
\hline \multicolumn{8}{|c|}{ Complement } \\
\hline $\mathrm{Clqb}$ & Rn00570480_m1 & $1.739^{\mathrm{a}}$ & $<0.001$ & 0.951 & & $1.654^{\mathrm{a}}$ & $<0.001$ \\
\hline C1-Inh & Rn01485600_m1 & 1.008 & & $1.541^{\mathrm{a}}$ & 0.005 & $1.553^{\mathrm{a}}$ & 0.009 \\
\hline $\mathrm{C} 3$ & Rn00566466_m1 & $4.297^{\mathrm{a}}$ & $<0.001$ & $1.193^{\mathrm{a}}$ & 0.010 & $5.126^{\mathrm{a}}$ & $<0.001$ \\
\hline \multicolumn{8}{|c|}{ Chemokine and cytokines } \\
\hline $\mathrm{Ccl} 2$ & Rn00580555_m1 & 1.294 & & $1.634^{\mathrm{a}}$ & 0.079 & $2.114^{\mathrm{a}}$ & 0.014 \\
\hline$\| 1 \mathrm{~b}$ & Rn00580432_m1 & $2.390^{\mathrm{a}}$ & $<0.001$ & $0.518^{\mathrm{a}}$ & $<0.001$ & 1.238 & \\
\hline$\| 6$ & Rn00561420_m1 & 1.119 & & 0.651 & & 0.728 & \\
\hline
\end{tabular}


Table 1 Age- and ovarian hormone-related changes in expression of genes related to microglial reactivity in the frontal cortex of middle-aged female rats (Continued)

\begin{tabular}{llcccc}
\hline Tgfb1 & Rn00572010_m1 & 0.898 & 0.057 & $\mathbf{1 . 5 0 0}^{\mathbf{a}}$ & $<0.001$ \\
Tnf & Rn99999017_m1 & 0.843 & 1.595 & 0.084 & $1.347^{\mathbf{a}}$ \\
\hline
\end{tabular}

Quiescent and activated microglial cells differ strikingly in the expression of macrophage-associated genes. Age- and ovariectomy-related changes in mRNA expression were measured by real-time PCR. The applied TaqMan assays were listed. RQ represents the expression of a given gene in response to aging or ovariectomy compared to basal (control) expression. RQ (age) represents the ratio of mRNA expression in middle-aged versus young rats. RQ (OVX) shows the ratio of mRNA levels in middle-aged OVX rats versus middle-aged ones. RQ (age+OVX) values correspond to the ratio of mRNA expression in middle-aged OVX rats compared to young ones. Statistical significance of the alterations was tested by analysis of variance (ANOVA) with Newman-Keuls post hoc test, and was considered significant at $P<0.05 ;{ }^{\text {a } R Q}$ values with statistically significant changes. $P$-values are indicated if $<0.1$. ${ }^{\mathrm{b}}$ Microglial marker genes.

differentiation antigen (Cd36). Similar to $\mathrm{Cd} 11 \mathrm{~b}$ and Cd18, expression of Cd32 (Figure 2A), Cd93 (Figure 2B) and Msr2 (Figure 2C) showed a 1.6-, 1.3- and 2.6-fold age-related increase, respectively. Expression of Cd32 and Msr2 enhanced further, whereas Cd93 expression decreased 0.8-fold after ovariectomy. Expression of Cd36 dropped 0.6-fold in the aging brain, which decreased further following ovariectomy (Figure 2D). Altogether, age and ovarian hormone deficiency caused 2.5- and 3.6-fold increase in the expression of $\mathrm{Cd} 32$ and Msr2, respectively. In contrast, $\mathrm{Cd} 36$ decreased 0.44 -fold.

$\mathrm{Cd} 11 \mathrm{~b} / \mathrm{Cd} 18$ and $\mathrm{Cd} 93$ recognize $\mathrm{C} 3$ activation fragments and C1q, respectively. Messenger RNA expression of $\mathrm{C} 1 \mathrm{q}$ (Figure 2E) and $\mathrm{C} 3$ (Figure 2F) increased in the aging frontal cortex 1.8- and 4.3-fold, respectively. The robust increase of $\mathrm{C} 3$ was amplified further after ovariectomy. Again, E2 reversed the increase of Cd11b, Cd18, $\mathrm{Cd} 32$ and Msr2 expression (Figure 2), which was in good correlation with the attenuation of $\mathrm{Cd} 45$ and $\mathrm{Cd} 86$ expression following ovariectomy (Figure 1).

\section{Ovarian hormone deficiency enhanced mRNA expression of toll-like receptor 4 and 9}

Microglial cells express Tlrs and co-receptors to recognize apoptotic cells, amyloid peptide and bacterial cell wall components among others [25,42]. Aging led to a 1.2- to 1.5-fold increase in the expression of Tlr4 and Tlr9. Ovariectomy caused comparable elevation (Figure 3B and C). Altogether, age and ovarian hormone deficiency resulted in 1.5- and 2.0-fold increase in the expression of Tlr4 and Tlr9. Changes in the expression of Tlr2 (Figure 3A) and Cd14 (Figure 3D) did not reach statistical significance.

Again, E2 attenuated the increase of Tlr4 and Tlr9 expression similarly to $\mathrm{Cd} 11 \mathrm{~b}, \mathrm{Cd} 18, \mathrm{Cd} 32, \mathrm{Cd} 45, \mathrm{Cd} 86$ and Msr2.

Aging and ovarian hormone deprivation increased mRNA expression of RT1-Aw2

MHC class I antigens RT1-Aw2 and RT1-N1 showed significant age- and ovariectomy-related increase in their expression (Table 1). RT1-Aw2 showed 14.7- and 1.5fold age- and ovariectomy-related increase, respectively.
Altogether, there was a 21.7-fold increase in mRNA expression of RT1-Aw2.

Age and ovariectomy altered the expression of genes involved in the regulation of microglia reactivity

We examined age- and ovarian hormone deficiencyrelated alterations of key components of neuronal inhibitory pathways and estrogen signaling, which play a pivotal role in the regulation of microglia reactivity. Neurons tightly control the reactivity of microglial cells by expressing inhibitory ligands [43]. We measured expression of six genes encoding neuronal ligand-microglial receptor pairs such as Cd47-Sirpa, Cd200-Cd200r and Cx3cl1-Cx3cr1. As a result of aging and ovariectomy, we found 0.8 - to 0.7 -fold decrease in the expression of Cd200 (Figure 4D) and Cd200r (Figure 4C). We observed a 0.75-fold decrease in Cx3cl1 (Figure 4F), and a 1.3-fold increase in Cx3cr1 (Figure 4E). There was no change in $\mathrm{Cd} 47$ (Figure 4B) and Sirpa (Figure 4A).

We also determined age- and ovarian hormonedependent alterations in the expression of Esr1 and Esr2 genes encoding $E R \alpha$ and $E R \beta$, respectively. Both age and ovarian hormone deficiency altered their expression. Expression of Esr1 decreased (Figure 5A), whereas Esr2 increased (Figure 5B) during aging. Ovariectomy decreased the transcription of both receptors. Altogether, aging and ovariectomy caused a 0.6-fold decrease in Esr1 and a 1.8fold increase in Esr2 expression.

E2 replacement ten days after ovariectomy rescued the transcription of Esr1 and Esr2. These results suggested that key genes in control mechanisms for microglia reactivity were altered in the frontal cortex of middle-aged, ovarian hormone-deprived rats.

\section{Expression of selected cytokines and other immune genes}

We studied the expression of three pro-inflammatory cytokines (Il1b, Il6, Tnf) and astrocytic Tgfb1. The expression of Illb increased during aging and dropped after ovariectomy. Tgfb1 did not change during aging, but was enhanced significantly after ovariectomy. Il6 and Tnf showed no significant alteration. As a result of aging and ovariectomy, only Tgfb1 was enhanced 1.3-fold, 
Table 2 Data analysis showed alterations in the expression of macrophage-associated, regulatory and proinflammatory genes in cortical regions of postmenopausal women, indicating overlapping changes with the rat results

\begin{tabular}{|c|c|c|c|c|c|c|c|}
\hline \multirow[b]{2}{*}{ Symbol } & \multirow[b]{2}{*}{ Probeset } & \multicolumn{4}{|c|}{ Microarray analysis } & \multicolumn{2}{|c|}{ Real-time PCR } \\
\hline & & $\overline{F C ~(P G)}$ & $P *(P G)$ & FC (SG) & $P *(\mathrm{~S} \mathrm{G})$ & RQ (age+OVX) & $P$ (age $+O$ \\
\hline \multicolumn{8}{|c|}{ Macrophage-associated genes } \\
\hline \multicolumn{8}{|c|}{ Phagocytic and scavenger receptors } \\
\hline$C D 11 b^{b}$ & 205786_s_at & 1.341 & 0.918 & 1.145 & 0.832 & 2.778 & $<0.001$ \\
\hline $\mathrm{CD} 18^{\mathrm{b}}$ & 1555349_a_at & $2.808^{\mathrm{a}}$ & 0.697 & $2.331^{\mathrm{a}}$ & 0.629 & 2.164 & $<0.001$ \\
\hline FCGR2b & 210889_s_at & 1.020 & 1.000 & 1.228 & 0.746 & 2.488 & $<0.001$ \\
\hline CD36 & 228766_at & $0.670^{\mathrm{a}}$ & 0.942 & 0.812 & 0.793 & 0.440 & $<0.001$ \\
\hline RAGE & 217046_s_at & 1.000 & 1.000 & 0.991 & 0.960 & 1.066 & \\
\hline
\end{tabular}

Recognition receptors

\begin{tabular}{|c|c|c|c|c|c|c|c|}
\hline CD14 & 201743_at & $5.134^{\mathrm{a}}$ & 0.697 & $2.817^{\mathrm{a}}$ & 0.629 & 1.174 & \\
\hline $\mathrm{CD} 40^{\mathrm{b}}$ & 205153_s_at & 1.025 & 0.877 & 0.967 & 0.881 & 1.481 & 0.054 \\
\hline$C D 45^{b}$ & 212588_at & $1.903^{\mathrm{a}}$ & 0.918 & 1.152 & 0.938 & 1.799 & $<0.001$ \\
\hline$C D 86^{b}$ & 205685_at & 1.466 & 0.697 & 1.094 & 0.709 & 1.782 & $<0.001$ \\
\hline TLR2 & 204924_at & $1.832^{\mathrm{a}}$ & 0.781 & 1.035 & 1.000 & 1.015 & \\
\hline TLR4 & 221060_s_at & 1.152 & 1.000 & $1.634^{\mathrm{a}}$ & 0.629 & 1.512 & $<0.001$ \\
\hline TLR9 & 223903_at & & & 1.182 & 0.629 & 1.907 & 0.008 \\
\hline CD74 ${ }^{b}$ & 1567628_at & $2.232^{\mathrm{a}}$ & 0.697 & $1.631^{\mathrm{a}}$ & 0.689 & 2.255 & 0.047 \\
\hline \multicolumn{8}{|c|}{ Signaling } \\
\hline NOS2 & 212531_at & 0.965 & 1.000 & 1.002 & 1.000 & 1.041 & \\
\hline IRF7 & 208436_s_at & 1.047 & 1.000 & 1.341 & 0.629 & 4.748 & $<0.001$ \\
\hline IRF9 & 203882_at & 1.105 & 1.000 & 1.242 & 0.629 & 1.746 & $<0.001$ \\
\hline
\end{tabular}

Microglial receptors

\begin{tabular}{|c|c|c|c|c|c|c|c|}
\hline CD200R & 1552875_a_at & 0.990 & 0.942 & 0.990 & 0.763 & 0.722 & $<0.001$ \\
\hline CX3CR1 & 1568934_at & $0.557^{\mathrm{a}}$ & 0.967 & 0.960 & 1.000 & 1.341 & 0.005 \\
\hline \multicolumn{8}{|c|}{ Neuronal ligand } \\
\hline CD200 & 209582_s_at & 0.886 & 1.000 & $0.497^{\mathrm{a}}$ & 0.629 & 0.829 & \multirow[t]{2}{*}{0.019} \\
\hline SIRPA & 202897_at & 0.799 & 0.877 & 0.908 & 0.750 & 0.987 & \\
\hline CX3CL1 & 823_at & $0.462^{\mathrm{a}}$ & 0.697 & $0.575^{\mathrm{a}}$ & 0.629 & 0.754 & $<0.001$ \\
\hline \multicolumn{8}{|c|}{ Complement and cytokine genes } \\
\hline \multicolumn{8}{|c|}{ Complement } \\
\hline $\mathrm{Clq}$ & 202953_at & $4.364^{\mathrm{a}}$ & 0.697 & $2.319^{\mathrm{a}}$ & 0.629 & 1.654 & $<0.001$ \\
\hline $\mathrm{C} 1-\mathrm{INH}$ & 200986_at & 1.419 & 0.877 & $1.723^{\mathrm{a}}$ & 0.629 & 1.553 & 0.009 \\
\hline $\mathrm{C} 3$ & 217767_at & $1.577^{\mathrm{a}}$ & 0.942 & 1.246 & 0.842 & 5.126 & $<0.001$ \\
\hline \multicolumn{8}{|c|}{ Chemokine and cytokines } \\
\hline $\mathrm{CCL} 2$ & 216598_s_at & $1.976^{\mathrm{a}}$ & 0.942 & $2.492^{\mathrm{a}}$ & 0.629 & 2.114 & \multirow[t]{3}{*}{0.014} \\
\hline IL $1 \mathrm{~b}$ & 205067_at & 0.669 & 0.984 & 0.743 & 0.763 & 1.238 & \\
\hline IL6 & 205207_at & $0.594^{\mathrm{a}}$ & 0.907 & 0.748 & 0.709 & 0.728 & \\
\hline TGFb1 & 203085_s_at & $1.812^{\mathrm{a}}$ & 0.781 & $1.988^{\mathrm{a}}$ & 0.629 & 1.347 & $<0.001$ \\
\hline TNF & 207113_s_at & & & & & 1.345 & \\
\hline
\end{tabular}

Differential expression of selected genes in the postcentral and superior frontal gyrus of pre- and postmenopausal women. Fold change (FC) corresponds to the ratio of the older and younger group mean expressions for a given gene. ${ }^{\mathrm{a}} \mathrm{FC}>1.5 ; P^{*}$ false discovery rate-adjusted raw $P$-value; $\mathrm{RQ}$ (age+OVX) values correspond to the ratio of mRNA expression in middle-aged OVX rats compared to young ones; ${ }^{b}$ conventional microglial marker genes are in bold. 

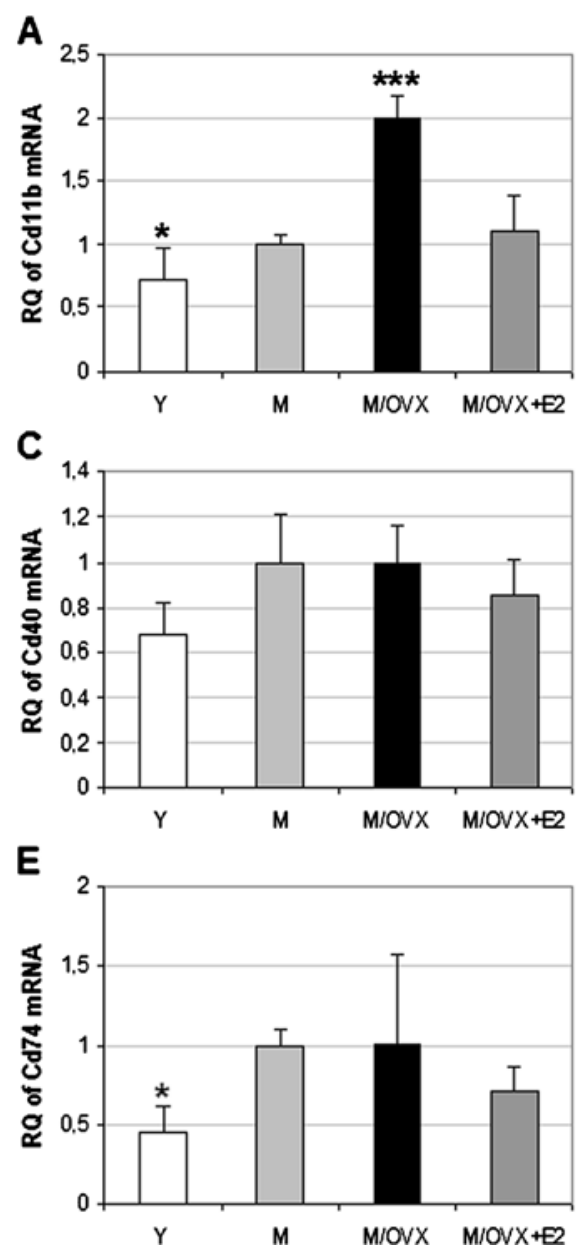

Figure 1 Age- and hormone-dependent alteration in the mRNA expression of widely used microglia marker genes in the frontal cortex of middle-aged female rats. Real-time PCR demonstrated age- and ovarian hormone-related increase in the transcription of Cd11b (A), Cd18 (B), Cd45 (D) and Cd86 (F). 17ß-estradiol (E2) replacement attenuated these changes. Cd40 (C) and Cd74 (E) expression did not change after ovariectomy. Error bars show SD of six samples for each group. Statistical significance of the alterations in different groups compared to middleaged female rats (M) was analyzed by analysis of variance (ANOVA) with Newman-Keuls post hoc test, and considered significant at $P<0.05$. Asterisks indicate significant changes: ${ }^{*}$ corresponds to $0.01<P<0.05$, ${ }^{* *}$ to $0.001<P<0.01$ and ${ }^{* * *}$ to $P<0.001$. $Y$, young rat; M/OVX, middle-aged ovariectomized $(\mathrm{OVX})$ rat; M/OVX+E2, middle-aged OVX rat treated chronically with E2.

indicating that a characteristic pro-inflammatory milieu did not develop in the ovarian hormone-deprived aging cortex.

We examined the expression of Ccl2 and found 1.6fold ovariectomy-related elevation in its expression, which was reversed by E2 (Table 1). Irf7 and Irf9, encoding IFN regulatory factors, increased during aging and intensified further after ovariectomy (Table 1).

\section{Microarray data analysis revealed strikingly similar changes of gene expression in the postcentral and superior frontal gyrus of postmenopausal women} To address the impact of menopause on gene expression in the human forebrain, we carried out an analysis of raw microarray data from our previous gene expression profiling study [20]. The expression of twenty-nine genes
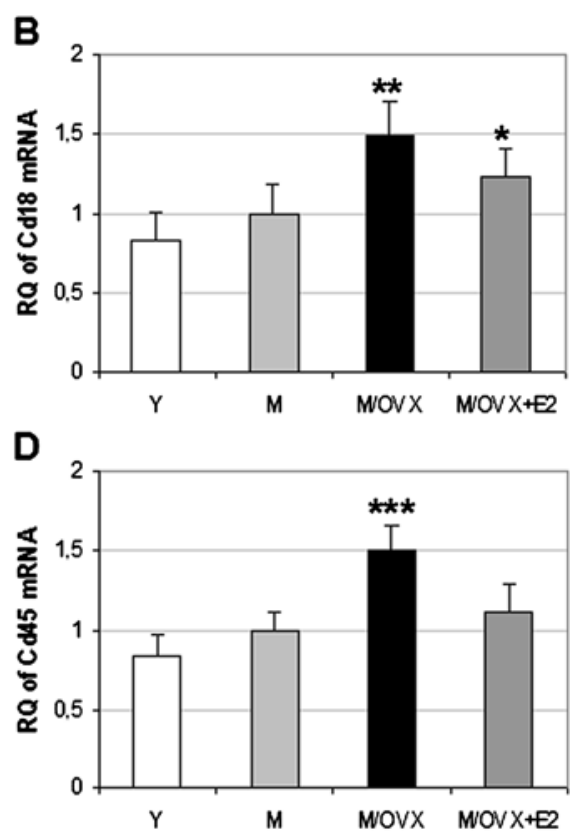

F

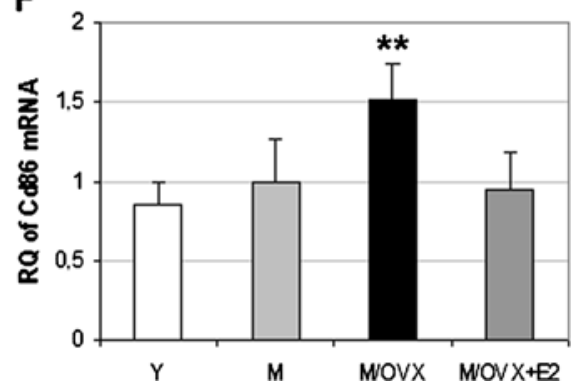

associated with the innate immune response was compared in the PG and SG from premenopausal versus postmenopausal women with an average age of 39 and 71 years, respectively. To identify differentially expressed genes in small samples, we used the raw FC values, as FC correlates well with reproducibility [44]. We considered alterations with $\mathrm{FC}>1.5$ to be reliable changes. Our analysis revealed up-regulation of CD14, CD18, CD45, TLR2, TLR4, CD74, C1q, C3, CCL2, and downregulation of CD36, CX3CR1, CX3CL1 and CD200 in postmenopausal women (Table 2).

\section{Discussion}

In this study, we demonstrated that menopause amplified the age-related increase in the expression of macrophage-associated genes in the frontal cortex. From 


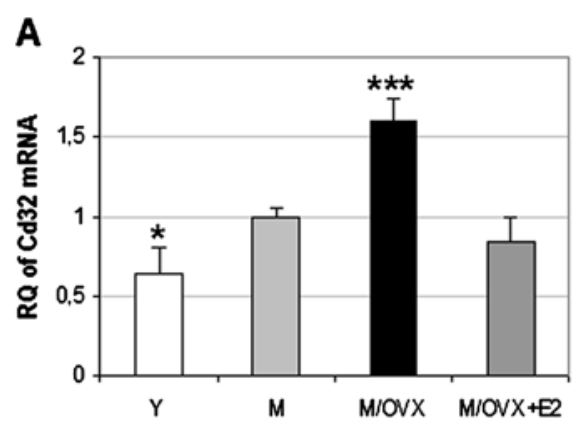

C

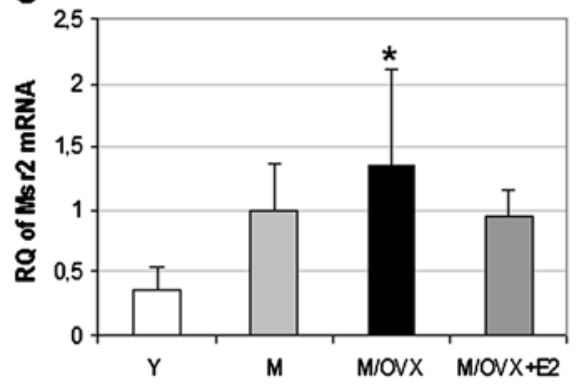

E

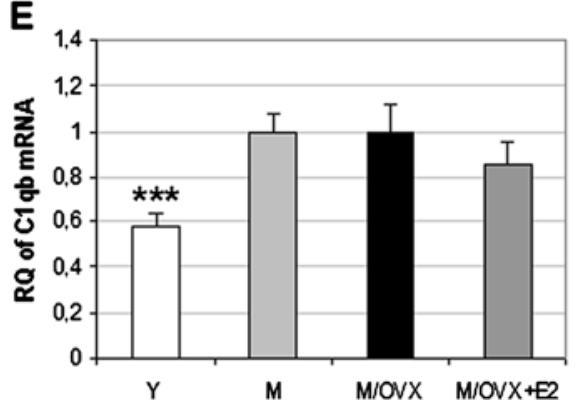

B

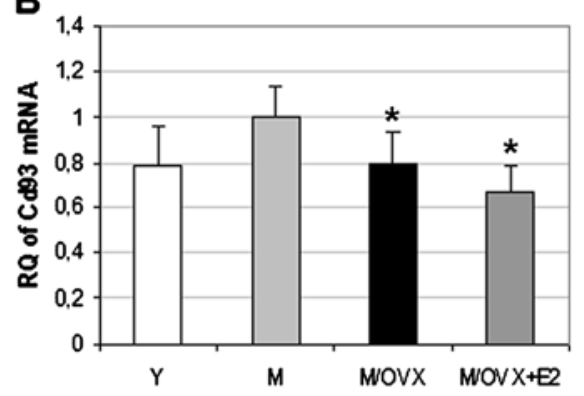

D

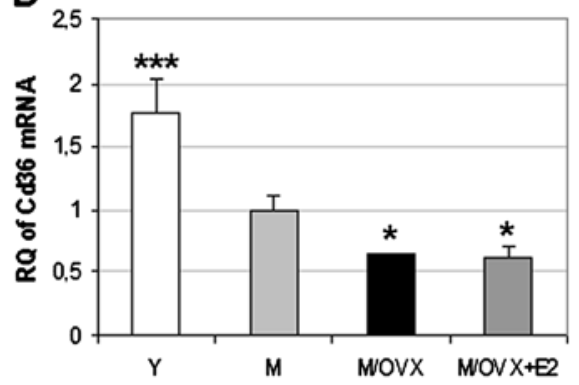

$\mathbf{F}$

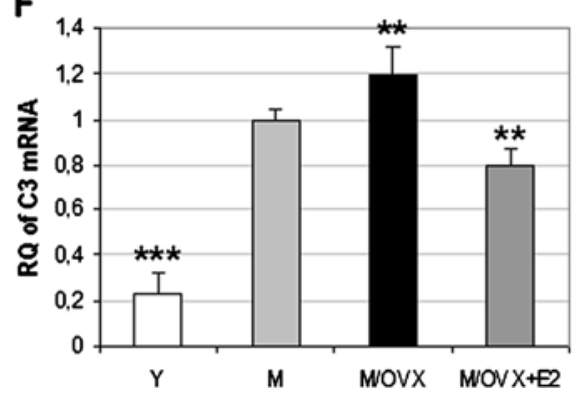

Figure 2 Age- and hormone-related changes in mRNA expression of genes related to phagocytosis. Real-time PCR demonstrated ageand ovariectomy-related increase in the expression of Cd32 (A), Msr2 (C), C1qb (E), C3 (F), and decrease of Cd93 (B), Cd36 (D). Error bars show SD of six biological samples. Statistical significance of the alterations in different groups compared to middle-aged female rats (M) was analyzed using analysis of variance (ANOVA) followed by Newman-Keuls post hoc test. Asterisks indicate changes with statistical significance: *corresponds to $0.01<P<0.05$, ${ }^{* *}$ to $0.001<P<0.01$ and ${ }^{* * *}$ to $P<0.001$. Y, young rat; $M / O V X$, middle-aged ovariectomized $(\mathrm{OVX})$ rat; $\mathrm{M} / \mathrm{OVX}+\mathrm{E} 2$, middleaged OVX rat with $17 \beta$-estradiol (E2) replacement.

the major findings we conclude that i) the microglia phenotype shifts from the resting towards the activated state in a rat model of menopause, ii) the shift is reversible, iii) altered expression of phagocytic receptors may indicate modified phagocytic activity, iv) impairment of regulatory mechanisms may contribute to the early state of microglia activation, and v) strikingly similar changes occur in the forebrain of postmenopausal women.

The microglia phenotype shifts from the resting toward the activated state in the frontal cortex of middle-aged ovariectomized rats

Slight up-regulation of Cd11b, Fcgr2b, Tlr9, RT1-Aw2, and $\mathrm{Cd} 74$ in the frontal cortex of middle-aged rats indicates an initial age-related alteration in microglial gene expression. Elevated expression of C1q, C3 and Il1b is in accord with previous studies [18-22]. As these genes are expressed in astrocytes and microglia, it is likely that changes of glial phenotypes are intertwined. It is worth noting that the expression of C1-Inh, encoding the sole regulator of the classical activation pathway [45], does not change, suggesting that the control of the classical pathway may be impaired.

Ovarian hormone deficiency enhanced the expression of Cd11b, Cd18, Cd32, Cd45, Cd86, Tlr4, RT1-Aw2, and decreased Cd36, reflecting an initial shift in the microglia phenotype. The increase in the expression of IFN regulatory factors Irf7 and Irf9 is in accord with the shift of microglia from the resting phenotype [46]. Downregulation of $\mathrm{Cd} 36$ [47] is also a characteristic feature of the acquired microglia phenotype. We suggest that down-regulation of Cd36 may underlie the decreased 

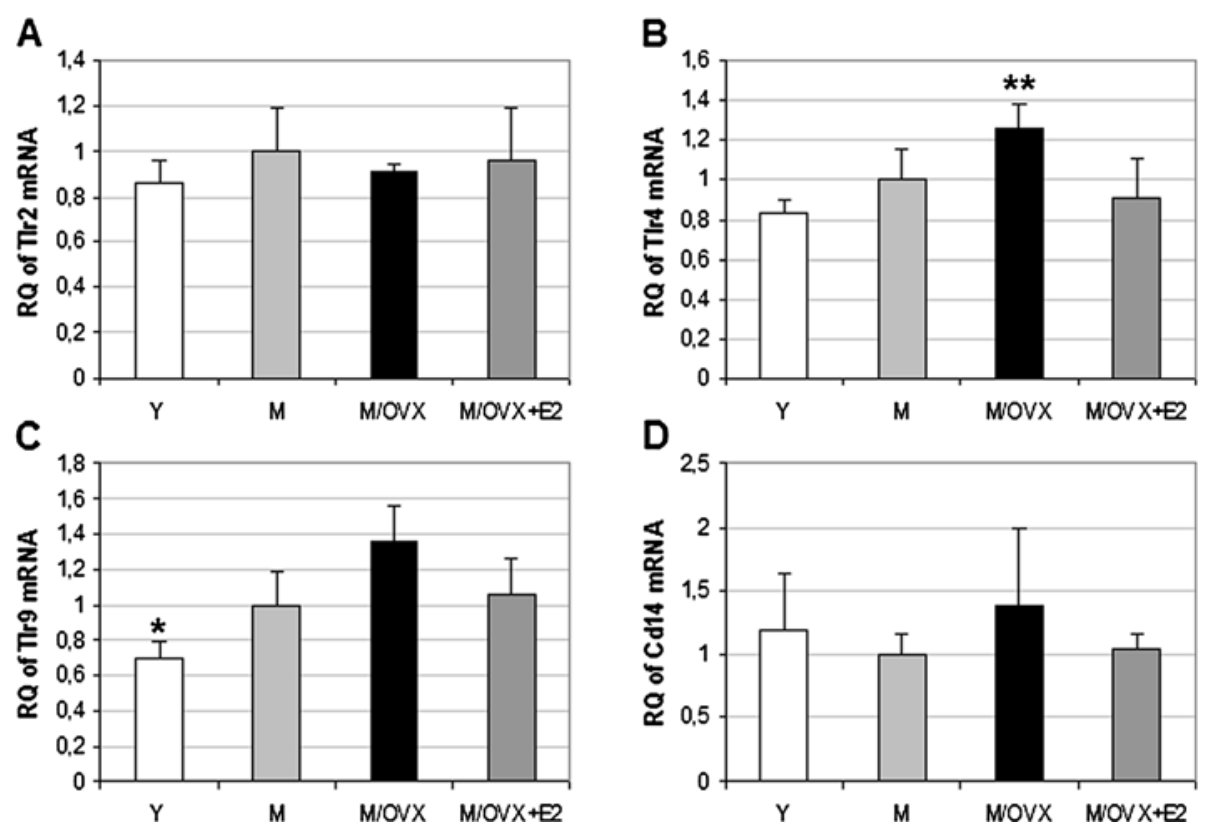

Figure 3 Age- and ovarian hormone-dependent regulation of genes encoding toll-like receptors and co-receptor Cd14 in the rat frontal cortex. TaqMan-based quantitative real-time PCR revealed changes in mRNA expression of Trr4 (B) and TIr9 (C). Tlr2 (A) and Cd14 (D) did not alter. Error bars show SD of six independent measurements. Statistical significance of the alterations in different groups compared to middleaged female rats (M) was calculated using analysis of variance (ANOVA) with Newman-Keuls post hoc test, and considered significant at $P<0.05$. Asterisks indicate changes with statistical significance: ${ }^{*}$ corresponds to $0.01<P<0.05$, ${ }^{* *}$ to $0.001<P<0.01$ and ${ }^{* * *}$ to $P<0.001$. $Y$, young rat; M/OVX, middle-aged ovariectomized (OVX) rat; M/OVX+E2, middle-aged OVX rat treated with 17ß-estradiol (E2).

internalization of amyloid- $\beta$ by aged compared to young microglia [48].

Our human microarray data analysis identified strikingly similar changes. Based on these results we propose that in the PG and SG of postmenopausal women the microglia phenotype is characterized by the upregulation of CD11b, CD14, CD18, CD45, CD74, CD86, TLR4, and down-regulation of CD36. Notably, the expression of CD40 and NOS2 does not change.

\section{The effect of E2 indicates that the shift in microglia phenotype is reversible}

E2 replacement attenuated the ovarian hormone deprivation-related increase in the expression of $\mathrm{Cd} 11 \mathrm{~b}$, Cd18, Fcgr2b, Msr2, Cd45, Cd86, Tlr4, RT1-Aw2 and RT1-N1. Down-regulation of these macrophage-associated genes suggests that E2 may attenuate microglial activation. This notion is consistent with the regulatory role of E2 on macrophage functions [49] and microglia activation in inflammatory $[12,50]$ and injury [51] models.

\section{Complement-mediated phagocytosis may increase in the middle-aged cortex}

Age-dependent elevation takes place in the expression of C1q, and its phagocytic receptor CD93 in the frontal cortex of female rats. C1q binds to pathogens and apoptotic cells, directly or through antibodies and pentraxins [45]. C1q binding initiates the classical pathway of complement resulting in recruitment of phagocytes, phagocytosis of apoptotic cells and destruction of invading pathogens. In the brain $\mathrm{C} 1 \mathrm{q}$ also recognizes and binds to proteins with pathogenic conformation, such as amyloid- $\beta$ and prion protein. Elevated expression of $\mathrm{C} 1 \mathrm{q}$ may facilitate early recognition and phagocytosis of pathogenic substances in the aging brain.

C3 is the central component of the complement system [45]. Activation pathways converge at C3, and its proteolytic fragments are ligands for complement receptors on various cell types including microglia. The interaction between C3 fragment iC3b and CR3 links complement activation and phagocyte functions. In the presence of $\mathrm{C} 3$ activators, elevated expression of C3 and CR3 may contribute to early steps of microglia activation, often referred to as microglial priming [2]. This notion is supported by the co-localization of C3b fragments and activated microglia in humans and in rodent models of neuroinflammatory diseases [52-54]. The impact of the interaction between C3 fragments and CR3 on microglia priming has been recently demonstrated in a multiple sclerosis model [54].

\section{Neuronal inhibitory pathways and estrogen signaling are altered after menopause}

Neuronal inhibitory ligands play a pivotal role in the tight control of microglia reactivity $[24,43]$. We demonstrated age- and ovariectomy-related alterations in the expression 

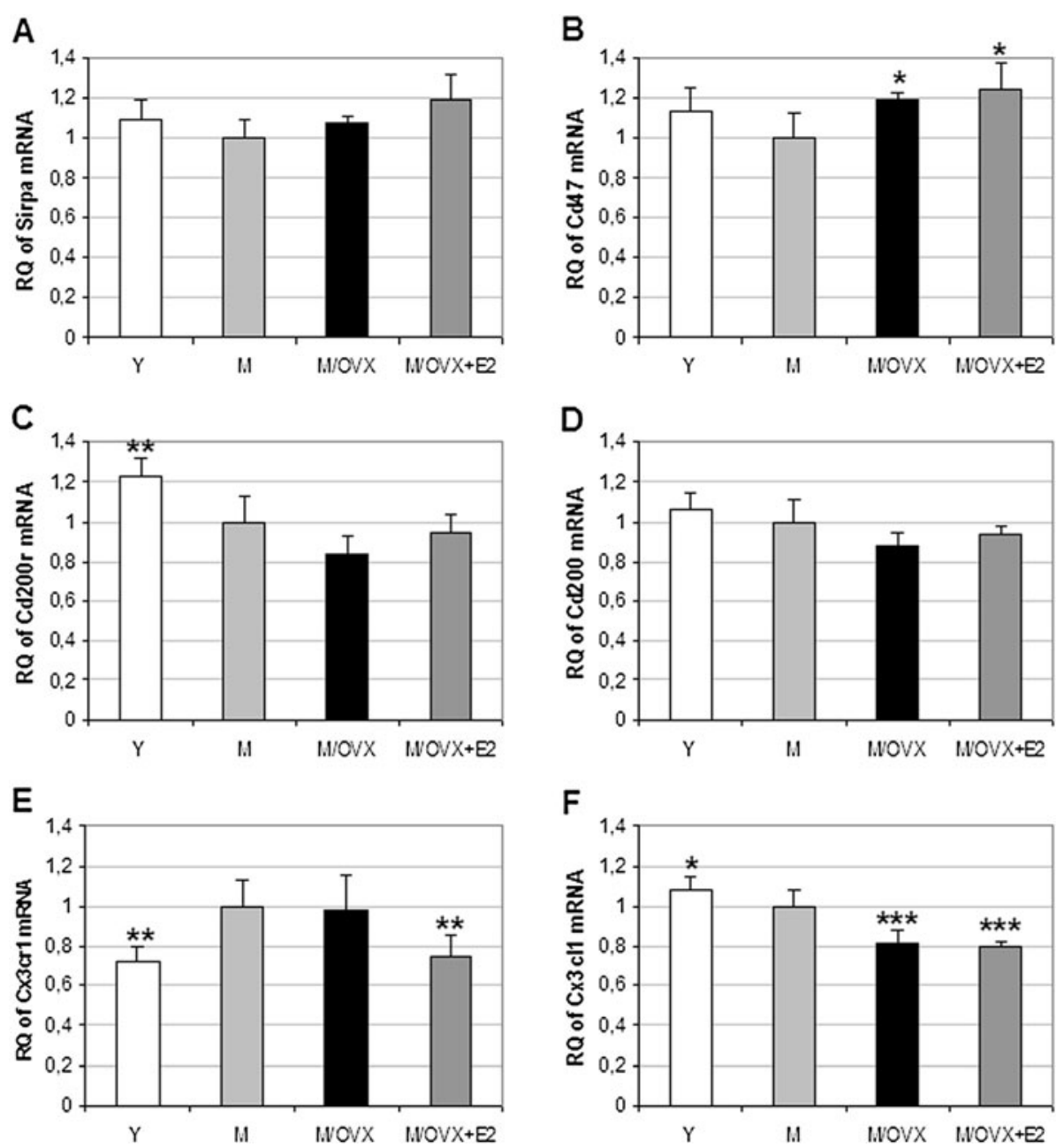

Figure 4 Age- and ovarian hormone-dependent regulation of genes encoding microglial receptors and their inhibitory neuronal ligands in the rat frontal cortex. TaqMan-based quantitative real-time PCR revealed no change in Sirpa (A), increase in the expression Cd47 (B), decrease in mRNA expression of Cd200r (C), Cd200 (D) and Cx3cl1 (F). Cx3cr1 (E) increased during aging. Error bars show SD of six independent measurements. Statistical significance of the alterations in different groups compared to middle-aged female rats (M) was determined by analysis of variance (ANOVA) with Newman-Keuls post hoc test, and considered at $P<0.05$. Asterisks indicate changes with statistical significance: ${ }^{*}$ Corresponds to $0.01<P<0.05$, ${ }^{* *}$ to $0.001<P<0.01$ and ${ }^{* * *}$ to $P<0.001$. Y, young rat; $\mathrm{M} / \mathrm{OVX}$, middle-aged OVX rat; $\mathrm{M} / \mathrm{OVX}+\mathrm{E} 2$, middle-aged ovariectomized $(\mathrm{OVX})$ rat treated with $17 \beta$-estradiol (E2).

of inhibitory ligands, including down-regulation of Cx3cl1 and $\mathrm{Cd} 200$, and up-regulation of $\mathrm{Cd} 47$ in the frontal cortex of middle-aged rats. The expression of microglial receptors for these ligands also showed changes, including down-regulation of $\mathrm{Cd} 200 \mathrm{r}$ and up-regulation of Cx3cr1. Decreased expression of $\mathrm{Cd} 200 \mathrm{r}$ is in accord with the age-related decrease in the expression of CD200R protein in the mouse brain [55]. CD200 fusion protein decreases microglia activation in the hippocampus of aged rats [56]. These data suggest that decreased expression of $\mathrm{Cd} 200$ and $\mathrm{Cd} 200 \mathrm{r}$ may contribute to the increased expression of macrophage-associated genes. In the PG and SG of postmenopausal women, downregulation of CD200 and CX3CL1 also indicates the impairment of major regulatory mechanisms for the control of microglia reactivity.

Estrogen signaling is also involved in the regulation of microglia reactivity $[4,50]$. Direct regulation is supported by the presence of ER $\alpha$ and ER $\beta$ in microglial cells [9] and by the well-known effects of E2 on macrophages [49]. However, ER $\alpha$ and ER $\beta$ are also expressed in neurons, astrocytes [57], and oligodendrocytes [58], so the role of indirect effects cannot be ruled out either. Here, we provide evidence for inverse age-related regulation of $E R \alpha$ and ER $\beta$. Decreased expression of ER $\alpha$ together with the declining levels of E2 is likely to reduce estrogen signaling in the aging rat cortex following ovariectomy. However, we found no sign of alteration of ESR1 


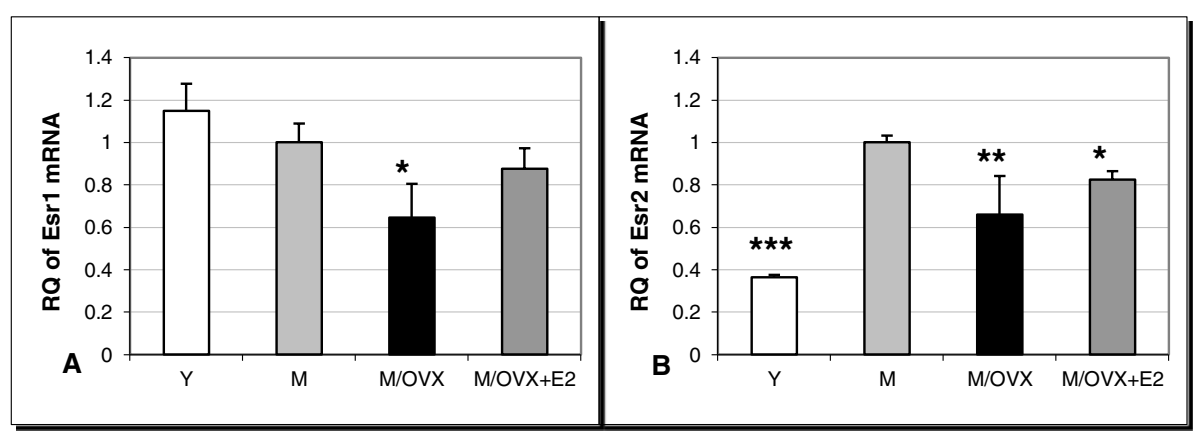

Figure 5 Age- and ovarian hormone-dependent regulation of mRNA expression of estrogen receptors in the rat frontal cortex. We measured age- and hormone-dependent changes by TaqMan-based quantitative real-time PCR in mRNA expression of Esr1 (A) and Esr2 (B), encoding ERa and ERß, respectively. Error bars show SD of six independent measurements. Asterisks indicate changes with statistical significance: ${ }^{*}$ corresponds to $0.01<P<0.05$, ${ }^{* *}$ to $0.001<P<0.01$ and ${ }^{* * *}$ to $P<0.001$. $Y$, young rat; $M$, middle-aged female rat; $M / O V X$, middle-aged ovariectomized $(\mathrm{OVX})$ rat; $\mathrm{M} / \mathrm{OVX}+\mathrm{E} 2$, middle-aged OVX rat with 17ß-estradiol (E2) replacement.

and ESR2 expression in the forebrain of postmenopausal women.

Summing up, the results provide evidence for microglial activation in the cortex of middle-aged rats following surgical menopause. Based on the overlapping changes from rodent and human studies, we propose that in the forebrain of postmenopausal women the microglia phenotype shifts from the resting towards the reactive state, which is characterized by up-regulation of CD11b, CD18, CD45, CD74, CD86, TLR4, down-regulation of CD36 and unchanged CD40 expression. This early state of activation, called microglial priming, seems to be reversible, as E2 replacement attenuates the expression of macrophage-associated genes in the rat frontal cortex. Microglia priming results in a phenotype with a lower threshold for subsequent activation [2,59]. It is proposed that in the presence of primed microglia, systemic infection and inflammation pose a higher threat for the aging brain [59].

\section{Abbreviations \\ ANOVA: Analysis of variance; CR3: Complement receptor type 3; Cd1 1b: Alpha chain of CR3; Cd14: Monocyte differentiation antigen; Cd18: Beta chain of CR3; Cd32: Fcy receptor 2a; Cd36: Leukocyte differentiation antigen; Cd40: TNF receptor superfamily member 5; Cd45: Leukocyte common antigen; Cd74: MHC class II-associated invariant chain; Cd86: B72 antigen; Cd93: Phagocytic C1q receptor; E2: 17ß-estradiol; FC: Fold change; Gapdh: Glyceraldehyde-3-phosphate dehydrogenase; Gusb: Glucuronidase beta; Hprt: Hypoxanthine guanine phosphoribosyl- transferase; IFN: Interferon; Msr2: Macrophage scavenger receptor 2; OVX: Ovariectomized; PCR: Polymerase chain reaction; PG: Postcentral gyrus; Ppia: Peptidyl-prolyl isomerase A; RQ: Relative quantity; SG: Superior frontal gyrus; TLDA: TaqMan low density array; Tlr: Toll-like receptor; TNF: Tumor necrosis factor.}

\section{Competing interests}

The authors declare that they have no competing interests.

\section{Authors' contributions}

MS, ZL designed the study. MS, EH, and IK collected the tissues; IK isolated the frontal cortices. MS, EH, and IL ran and analyzed real-time PCR. NB, and CC collected the microarray data. NS performed microarray data analysis. MS, and $\mathrm{ZL}$ wrote the manuscript. All authors have read and approved the final version of the manuscript.

\section{Acknowledgements}

This work was supported by grants from the Hungarian Scientific Research Fund (OTKA 100722K) and from the European Community's Seventh Framework Programme (FP7/2007-2013, No.245009). The study was also supported in part by TÁMOP-4.2.1.B-11/2/KMR-2011-0002. We thank Hajni Bekó for her excellent technical work.

\section{Author details}

${ }^{1}$ Laboratory of Endocrine Neurobiology, Institute of Experimental Medicine, Hungarian Academy of Sciences, Szigony utca 43, Budapest 1083, Hungary. ${ }^{2}$ Faculty of Information Technology, Pázmány Péter Catholic University, Práter utca 50/A, Budapest 1083, Hungary. ${ }^{3}$ Faculty of Veterinary Science, Szent István University, István utca 2, Budapest 1078, Hungary. ${ }^{4}$ Pharmacology and Drug Safety Research, Gedeon Richter Plc, Gyömrői út 19-21, Budapest 1103 Hungary. ${ }^{5}$ Institute for Brain Aging and Dementia, University of California, Irvine, CA 92697-4540, USA.

Received: 10 October 2012 Accepted: 13 November 2012 Published: 3 December 2012

\section{References}

1. Hanisch $\mathrm{U}$, Kettenmann $\mathrm{H}$ : Microglia: active sensor and versatile effector cells in the normal and pathologic brain. Nat Neurosci 2007 10:1387-1394

2. Dilger $\mathrm{R}$, Johnson R: Aging, microglial cell priming, and the discordant central inflam-matory response to signals from the peripheral immune system. J Leukoc Biol 2008, 84:932-939.

3. Brown C, Mulcahey T, Filipek N, Wise P: Production of proinflammatory cytokines and chemokines during neuroinflammation: novel roles for estrogen receptors $\alpha$ and $\beta$. Endocrinol 2010, 151:4916-4925.

4. Mor G, Nilsen J, Horvath L, Bechmann I, Brown S, Garcia-Segura L, Naftolin F: Estrogens and microglia: a regulatory system that affects the brain. J Neurobiol 1999, 40:484-496.

5. Vegeto E, Belcredito S, Etteri S, Ghisletti S, Brusadelli A, Meda C, Krust A, Dupont S, Ciana P, Chambon P, Maggi A: Estrogen receptor-a mediates the brain anti-inflammatory activity of estradiol. Proc Natl Acad Sci USA 2003, 100:9614-9619.

6. Tiwari-Woodruff S, Morales L, Lee R, Voskuhl R: Differential neuroprotective and anti-inflammatory effects of estrogen receptor (ER) a and ER $\beta$ ligand treatment. Proc Natl Acad Sci USA 2007, 104:14813-14818.

7. Lewis D, Johnson A, Stohlgren S, Harms A, Sohrabji F: Effects of estrogen receptor agonists on the regulation of the inflammatory response in astrocytes from young adult and middle-aged female rats. J Neuroimmunol 2008, 195:47-59. 
8. Kritzer M: Regional, laminar, and cellular distribution of immunoreactivity for ER alpha and ER beta in the cerebral cortex of hormonally intact, adult male and female rats. Cereb Cortex 2002, 12:116-128.

9. Sierra A, Gottfried-Blackmore A, Milner T, McEwen B, Bulloch K: Steroid hormone receptor expression and function in microglia. Glia 2008, 56:659-674.

10. Morrison J, Hof P: Life and death of neurons in the aging brain. Science 1997, 278:412-419.

11. Wise P, Dubal D, Rau S, Brown C, Suzuki S: Are estrogens protective or risk factors in brain injury and neurodegeneration? Reevaluation after the Women's Health Initiative. Endocr Rev 2005, 26:308-312.

12. Vegeto E, Belcredito S, Ghisletti S, Meda C, Etteri S, Maggi A: The endogenous estrogen status regulates microglia reactivity in animal models of neuroinflammation. Endocrinol 2006, 147:2263-2272

13. Gibson C, Constantin D, Prior M, Bath P, Murphy S: Progesterone suppresses the inflammatory response and nitric oxide synthase- 2 expression following cerebral ischemia. Exp Neurol 2005, 193:522-530.

14. VanLandingham J, Cekic M, Cutler S, Hoffman S, Stein D: Neurosteroids reduce inflammation after $\mathrm{TB}$ I through $\mathrm{CD} 55$ induction. Neurosci Lett 2007, 425:94-98.

15. Sunday $L$, Tran M, Krause D, Duckles S: Estrogen and progestagens differentially modulate vascular proinflammatory factors. Am J Physiol Endocrinol Metab 2006, 291:E261-E267.

16. Sárvári M, Kalló I, Hrabovszky E, Solymosi N, Tóth K, Likó I, Molnár B, Tihanyi K, Liposits Z: Estradiol replacement alters expression of genes related to neurotransmission and immune surveillance in the frontal cortex of middle-aged, ovariectomized rats. Endocrinol 2010, 151:3847-3862.

17. Sárvári M, Hrabovszky E, Kalló I, Galamb O, Solymosi N, Likó I, Molnár B, Tihanyi K, Szombathelyi Z, Liposits Z: Gene expression profiling identifies key estradiol targets in the frontal cortex of the rat. Endocrinol 2010, 151:1161-1176

18. Lu T, Pan Y, Kao S, Li C, Kohane I, Chan J, Yankner B: Gene regulation and DNA damage in the aging human brain. Nature 2004, 429:883-891.

19. Erraji-Benchekroun L, Underwood M, Arango V, Galfalvy H, Pavlidis P, Smyrniotopoulos P, Mann J, Sibille E: Molecular aging in human prefrontal cortex is selective and continuous throughout life. Biol Psychiatry 2005, 57:549-558.

20. Berchtold N, Cribbs D, Coleman P, Rogers J, Head E, Kim R, Beach T, Miller C, Troncoso J, Trojanowski J, Zielke H, Cotman C: Gene expression changes in the course of normal brain aging are sexually dimorphic. Proc Natl Acad Sci USA 2008, 105:15605-15610.

21. Blalock $E_{1}$ Chen $K$, Sharrow $K_{1}$ Herman J, Porter $N$, Foster T, Landfield P: Gene microarrays in hippocampal aging: statistical profiling identifies novel processes correlated with cognitive impairment. J Neurosci 2003 23:3807-3819.

22. Rowe B, Blalock E, Chen K, Kadish I, Wang D, Barrett J, Thibault O, Porter N, Rose G, Landfield P: Hippocampal expression analyses reveal selective association of immediate-early, neurogenetic, and myelinogenic pathways with cognitive impairment in aged rats. J Neurosci 2007, 27:3098-3110.

23. Ajami B, Bennett J, Krieger C, Tetzlaff W, Rossi F: Local self-renewal can sustain CNS microglia maintenance and function throughout adult life. Nat Neurosci 2007, 10:1538-1543.

24. Mildner A, Schmidt $H$, Nitsche M, Merkler D, Hanisch U, Mack M, Heikenwalder M, Bruck W, Priller J, Prinz M: Microglia in the adult brain arise from Ly-6ChiCCR2 monocytes only under defined host conditions. Nat Neurosci 2007, 10:1544-1553.

25. Kettenmann $H$, Hanisch U, Noda M, Verkhratsky A: Physiology of microglia. Physiol Rev 2011, 91:461-553.

26. Streit W, Graeber M, Kreutzberg G: Functional plasticity of microglia: a review. Glia 1988, 1:301-307.

27. Lynch A, Murphy K, Deighan B, O'Reilly J, Gun'ko Y, Cowley T, Gonzales-Reyes R, Lynch M: The impact of glial activation in the aging brain. Aging Dis 2010, 1:262-278.

28. Hart A, Wyttenbach A, Perry V, Teeling J: Age related changes in microglial phenotype vary between CNS regions: grey versus white matter differences. Brain Behav Immun 2012, 26:754-765.
29. Akiyama H, McGeer P: Brain microglia constitutively express beta-2 integrins. J Neuroimmunol 1990, 30:81-93.

30. Hickman S, Allison E, El Khoury J: Microglial dysfunction and defective $\beta$-amyloid clearance pathways in aging Alzheimer's disease mice. J Neurosci 2008, 28:8354-8360.

31. Jack C, Arbour N, Manusow J, Montgrin V, Blain M, McCrea E, Shapiro A, Antel J: TLR signaling tailors innate immune responses in human microglia and astrocytes. J Immunol 2005, 175:4320-4330.

32. Streit W, Graeber M, Kreutzberg G: Peripheral nerve lesion produces increased levels of major histocompatibility complex antigens in the central nervous system. J Neuroimmunol 1989, 21:117-123.

33. Frank M, Barrientos R, Biedenkapp J, Rudy J, Watkins L, Maier S: mRNA upregulation of $\mathrm{MHC}$ II and pivotal pro-inflammatory genes in normal brain aging. Neurobiol Aging 2006, 27:717-722.

34. Andersen C, Jensen J, Orntoft T: Normalization of real-time quantitative reverse transcription-PCR data: a model-based variance estimation approach to identify genes suited for normalization, applied to bladder and colon cancer data sets. Cancer Res 2004, 64:5245-5250.

35. Vandesompele J, De Preter K, Pattyn F, Peppe B, Van Roy N, De Paepe A, Speleman F: Accurate normalization of real-time quantitative RT-PCR data by geometric averaging of multiple internal control genes. Genome Biol 2002, 3:RESEARCH0034.1-0034.11.

36. Frommer D: Changing age of the menopause. Brit Med J 1964, 2:349-351.

37. McKinlay S, Brambilla D, Posner J: The normal menopause transition. Maturitas 1992, 14:103-115.

38. Wu Z, Irizarry R, Gentleman R, Martinez-Murillo F, Spencer F: A model-based background adjustment for oligonucleotide expression arrays. J Am Stat Assoc 2004, 99:909-917.

39. Smyth G: Linear models and empirical Bayes methods for assessing differential expression in microarray experiments. Stat Appl Genet Mol Biol 2004, 3:3.

40. Benjamini $Y$, Hochberg Y: Controlling the false discovery rate: a practical and powerful approach to multiple testing. J Royal Stat Soc Series B 1995 57:289-300.

41. Gentleman R, Carey V, Bates D, Bolstad B, Dettling M, Dudoit S, Ellis B, Gautier L, Ge Y, Gentry J, Homik K, Hothorn T, Huber W, lacus S, Irizarry R, Leisch F, Li C, Maechler M, Rossini AJ, Sawitzki G, Smith C, Smyth G, Tiemey $L$, Yang JYH, Zhang J: Bioconductor: open software development for computational biology and bioinformatics. Genome Biol 2004, 5:R80.

42. Lucin $\mathrm{K}$, Wyss-Coray $\mathrm{T}$ : Immune activation in brain aging and neurodegeneration: too much or too little? Neuron 2009, 64:110-122.

43. Tian L, Rauvala H, Gahmberg C: Neuronal regulation of immune responses in the central nervous system. Trends Immunol 2009, 30:91-99.

44. Consortium MAQC: The microarray quality control (MAQC) project shows inter- and intraplatform reproducibility of gene expression measurements. Nat Biotech 2006, 24:1151-1161.

45. Ricklin D, Hajishengallis G, Yang K, Lambris J: Complement: a key system for immune surveillance and homeostasis. Nat Immunol 2010, 11:785-797.

46. Khorooshi R, Owens T: Injury-induced type I IFN signaling regulates inflammatory responses in the central nervous system. J Immunol 2010, 185:1258-1264.

47. Coraci I, Husemann J, Berman J, Hulette C, Dufour J, Campanella G, Luster A, Silverstein S, El-Khoury J: CD36, a class B scavenger receptor, is expressed on microglia in Alzheimer's disease brains and can mediate production of reactive oxygen species in response to beta-amyloid fibrils. Am J Pathol 2002, 160:101-112.

48. Njie M, Boelen E, Stassen F, Steinbusch H, Borchelt D, Streit W: Ex vivo cultures of microglia from young and aged rodent brain reveal agerelated changes in microglial function. Neurobiol Aging 2012, 33:195. e1-e12.

49. Straub R: The complex role of estrogens in inflammation. Endocr Rev 2007, 28:52-574.

50. Tapia-Gonzalez S, Carrero P, Pernia O, Garcia-Segura L, Diz-Chaves Y: Selective oestrogen receptor (ER) modulators reduce microglia reactivity in vivo after peripheral inflammation: potential role of microglial ERs. J Endocrinol 2008, 198:219-230.

51. Gyenes A, Hoyk Z, Csakvari E, Siklos L, Parducz A: 17ß-estradiol attenuates injury-induced microglia activation in the oculomotor nucleus. Neurosci 2010, 171:677-682 
52. Stoltzner S, Grenfell T, Mori C, Wisniewski K, Wisniewski T, Selkoe D, Lemere

C: Temporal accrual of complement proteins in amyloid plaques in Down's syndrome with Alzheimer's disease. Am J Pathol 2000, 156:489-499.

53. Maier M, Peng Y, Yiang L, Seabrook T, Carroll M, Lemere C: Complement C3 deficiency leads to accelerated amyloid plaque deposition and neurodegeneration and modulation of the microglia/macrophage phenotype in amyloid precursor protein transgenic mice. J Neurosci 2008, 28:6333-6341.

54. Ramaglia V, Hughes T, Donev R, Ruseva M, Wu X, Huitinga I, Baas F, Neal J, Morgan B: C3-dependent mechanism of microglial priming relevant to multiple sclerosis. Proc Natl Acad Sci USA 2012, 109:965-970.

55. Shrivastava K, Gonzales P, Acarin L: The immune inhibitory complex CD200/CD200R is developmentally regulated in the mouse brain. J Comp Neurol 2012, 520:2657-2675.

56. Cox F, Carney D, Miller A, Lynch M: CD200 fusion protein decreases microglial activation in the hippocampus of aged rats. Brain Behav Immun 2011, 26:789-796.

57. Barreto G, Santos-Galindo M, Diz-Chavez Y, Pernia O, Carrero P, Azcoitia I, Garcia-Segura L: Selective estrogen receptor modulators decrease reactive astrogliosis in the injured brain: Effects of aging and prolonged depletion of ovarian hormones. Endocrinol 2009, 150:5010-5015.

58. Arevalo M, Santos-Galindo M, Bellini M, Azcoitia I, Garcia-Segura L: Actions of estrogens on glial cells: implications for neuroprotection. Biochim Biophys Acta 2010, 1800:1106-1112.

59. Perry V, Cunningham C, Holmes C: Systemic infections and inflammation affect chronic neurodegeneration. Nat Rev Immunol 2007, 7:161-167.

doi:10.1186/1742-2094-9-264

Cite this article as: Sárvári et al:: Menopause leads to elevated expression of macrophage-associated genes in the aging frontal cortex: rat and human studies identify strikingly similar changes. Journal of

Neuroinflammation 2012 9:264.

\section{Submit your next manuscript to BioMed Central and take full advantage of:}

- Convenient online submission

- Thorough peer review

- No space constraints or color figure charges

- Immediate publication on acceptance

- Inclusion in PubMed, CAS, Scopus and Google Scholar

- Research which is freely available for redistribution 